\title{
Introduction: Shipboard Literary Cultures and the Stain of the Sea
}

\section{Susann Liebich and Laurence Publicover}

On a collier plying the route between Sunderland and Quebec in the 1820s, the apprentice seaman Edward Beck kept a diary in which he recorded, among other things, the remarkable events of the voyage; his conversations with migrant passengers and with crew; his developing grasp of the art of navigation; and his private sensations as he crossed the vast Atlantic for the first time. Beck also recorded interactions with seabirds and with creatures of the deep, beginning one entry in mid-ocean thus:

Abundance of whales have been about the ship this afternoon, one in particular came very close to us \& gave me a full view of him, \& a most huge \& clumsy looking fellow he was, they play in the water much like porpoises $\&$ are $[\ldots]$

\footnotetext{
S. Liebich $(\bowtie)$

Heidelberg University, Heidelberg, Germany

L. Publicover

University of Bristol, Bristol, UK

e-mail: L.Publicover@bristol.ac.uk

(C) The Author(s), under exclusive license to Springer Nature

Switzerland AG 2021

S. Liebich, L. Publicover (eds.), Shipboard Literary Cultures, Maritime Literature and Culture, https://doi.org/10.1007/978-3-030-85339-6_1
} 


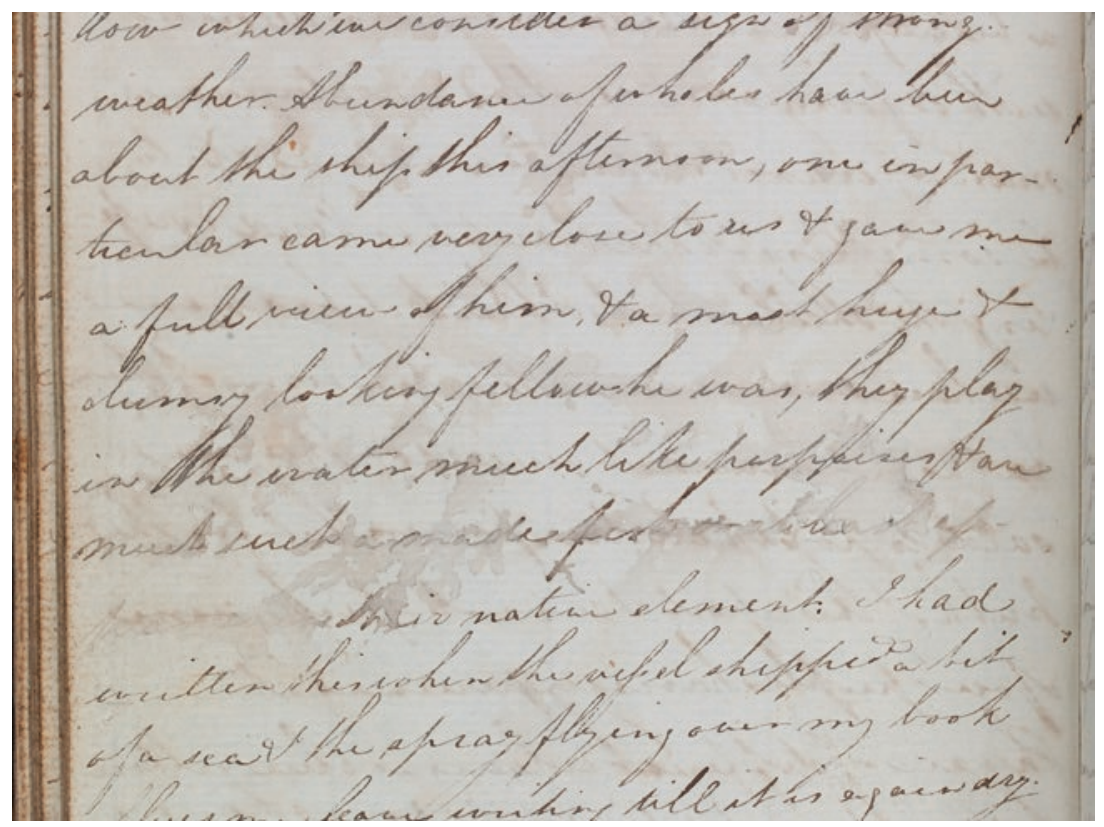

Fig. 1.1 Diary of Edward Beck. Caird Library, National Maritime Museum, London, JOD/266/1/1. (Used with Permission)

As the image above indicates (Fig. 1.1), the next two lines of Beck's account are difficult to make out, although the final three words of the sentence cited above clearly read 'their native element'. In the following sentence, which concludes the daily entry, Beck explains: 'I had written this when the [?vessel] shipped a bit of a sea \& the spray flying over my book obliges me to leave writing till it is again dry'. ${ }^{1}$ Having just branded the whale 'clumsy', Beck is immediately reminded that, unlike the whales, he is very much out of his native element.

The essays collected within this volume are concerned with how, usually in a more figurative sense, the sea can leave a stain on acts of reading, writing, and performing. Our contributors ask how literary practices are shaped by the experience of being at sea-and also how they forge that experience. They are interested, that is, both in how such practices adapt to the maritime world, and in how individual and collective shipboard

\footnotetext{
${ }^{1}$ Diary of Edward Beck, Caird Library, National Maritime Museum, London, JOD $/ 266 / 1,52$.
} 
experiences are structured through—and framed by-acts of reading, writing, and performing. In this respect, the following essays build on and extend studies of the 'where' of the production, circulation, and consumption of texts and knowledge. Such studies have persuasively argued that books-and by extension other material forms of texts and their performance-'cannot be understood outside their geographies', and that reading, writing, and performing are spatially situated and embodied practices. ${ }^{2}$ As Roger Chartier has noted, '[r] eading is not uniquely an abstract operation of the intellect: it brings the body into play, it is inscribed in a space and a relationship with oneself or with others'. ${ }^{3}$ The same holds true for writing and performing; and at sea, as our contributors demonstrate, such activities take place when the body is under peculiar forms of pressure, situated as it is within an environment - the shipboard community and the ocean beyond it-in which unique forms of social relation prevail.

There are, of course, many different kinds of shipboard community; indeed, one of the aims of this collection is to explore how specific shipboard environments encourage, hinder, or otherwise regulate literary activities. Our contributors indicate, for example, how ships travelling under steam or sail, or carrying migrants, coal, or whale oil, might shape acts of reading, writing, and performing in different ways; and further, they illustrate how different kinds of seafarer participate in such acts for differing reasons and to varying effects. Some essays focus on specific voyages or ships, while others range across vessels to compare instances of reading, writing, and performing aboard them. Though our contributors focus predominantly on ships with Anglophone seafarers, they follow them through the world's oceans, while vessels under scrutiny range from a man-of-war participating in the English Civil War (1642-51) to contemporary container ships, with those of the nineteenth century-perhaps the greatest age of Anglo-American maritime mobility—best represented.

\footnotetext{
${ }^{2}$ Miles Ogborn and Charles W.J. Withers, 'Introduction: Book Geography, Book History' in Ogborn and Withers (eds), Geographies of the Book (Farnham: Ashgate, 2010), 1-25 (25). For a classic study of the 'where' of reading, see Robert Darnton, 'First Steps Toward a History of Reading', in The Kiss of Lamourette: Reflections in Cultural History (New York: W. W. Norton, 1990), 154-187. See also David N. Livingstone, 'Science, Text and Space: Thoughts on the Geography of Reading', Transactions of the Institute of British Geographers 30.4 (2005), 391-401; and Innes M. Keighren, 'Geographies of the Book: Review and Prospect', Geography Compass 7.11 (2013), 745-758. For a study of space and performance, see 'Space on the Early Modern Stage', a special journal issue ed. Chloe Preedy and Laurence Publicover (Cahiers Élisabéthains 88.1 [2015], 7-180).

${ }^{3}$ Roger Chartier, The Order of Books, trans. Lydia G. Cochrane (Cambridge: Polity Press, 1994), 8 .
} 
A transhistorical approach is appropriate to a volume focused on a site that invites us to think in unusual ways about time itself. As the editors of the recent volume Oceanic Histories (2018) note, the 'fluid histories of oceans and seas' can be 'productively disruptive' to conventional historiography, charting as they do an area whose links to sovereignty-and its associated temporalities-are complex and often fraught. ${ }^{4}$ While the design, number, and location of ships on the oceans vary across history, while human ideas about and attitudes towards the oceans are significantly determined by specific historical circumstances, and while the chemical and biotic composition of the oceans are themselves historical (and for the past few centuries increasingly influenced by human activity), 'oceanic thinking' nonetheless involves acknowledging warps and ruptures in time as it is commonly experienced. Crossing latitudes throws the structure of seasons into uncertainty, while the lack of a built environment uproots seafarers from a specific historical culture. Consistently, humans crossing oceans to access different cultures record a sense of leaping backwards or forwards in time, and they have also called the oceans themselves 'timeless'; and however suspicious we may be of such a notion, given our environmental knowledge and scholarly training, we should also remain alert to the forms of ocean history that do, indeed, upend linear time - that is, to the continuities that exist in the experiences of those who take to sea across the centuries. While taking us into many different kinds of shipboard environment and dealing with seafarers of various stamps (including several women, whose voices are often absent in maritime studies) ${ }^{5}$ the case studies offered here suggest that the nature of seafaring complicates any clean breaks between historical epistemes.

\footnotetext{
${ }^{4}$ David Armitage, Alison Bashford, and Sujit Sivasundaram, 'Introduction: Writing World Oceanic Histories' in Armitage, Bashford, and Sivasundaram (eds), Oceanic Histories (Cambridge: Cambridge University Press, 2018), 1-27 (22).

${ }^{5}$ There are notable exceptions: important contributions to scholarship on women seafarers include Jo Stanley, From Cabin 'Boys' to Captains: 250 Years of Women at Sea (Stroud, Gloucestershire: The History Press, 2016); Jo Stanley, Women and the Royal Navy (London: IB Taurus, 2017); Joan Druett, Petticoat Whalers: Whaling Wives at Sea (Auckland: Collins, 1991); Joan Druett, She Captains: Heroines and Hellions of the Sea (New York: Simon \& Schuster, 2000); Lorraine Coons, "From "Company Widow" to "New Women": Female Seafarers aboard the "Floating Palaces" of the Interwar Years', International Journal of Maritime History 20.2 (2008), 143-74; and Sari Maenpaa, 'Women below Deck: Gender and Employment on British Passenger Liners, 1860-1938', The Journal of Transport History 25.2 (2004), 57-74.
} 
At the same time, our collection pays heed to the substantial differences between shipboard experiences-differences marked by historical period, and also by many other factors. It is chastening to think that, while some seafarers analysed within these essays crossed oceans while performing Shakespeare or while playing chamber music, on one specific form of British and American vessel, the slave ship, 'performing' meant being forced to dance on deck to musical accompaniment. ${ }^{6}$ As Stephen Berry explains in his contribution to this volume, enslaved peoples crossing the Atlantic sometimes found great solace in reading; but their opportunities to engage in the kinds of literary activities that, for many seafarers, made long-distance voyages tolerable, were of course severely limited. This is an extreme example. But there are also finer distinctions to be made between the forms of privilege afforded various kinds of seafarer. The same voyage can look markedly different to a steerage-class and a cabin-class passenger, or depending on whether one is a captain or an ordinary seaman; a man or a woman; English or Irish. There are other factors-to some extent, but not entirely historically contingent - that also shape the experience of being at sea. Communication with the outside world, increasingly providing a link between land and even the most remote locations at sea, has significantly altered what the English poet Lord Byron dubbed 'nautical existence'. ${ }^{7}$ Oceanographers speak wistfully of how contemporary research vessels, now much less cut off, lack the close bonds between shipmates that were typical thirty years ago (access to email is, they report, a mixed blessing at best). The gradual-and far from linear-transition between sail and steam also significantly affected what it meant to be at sea, not least because those on ships powered by steam had a better idea of how long their voyage was likely to last and were, relatively speaking, less exposed to the risks of seafaring.

In offering close examinations of shipboard literary cultures and their similarities and differences, then, this volume offers a specific lens through which to consider the historicity of the oceans and the nature of human relations with them: for while our contributors are concerned with how

${ }^{6}$ See Marcus Rediker, The Slave Ship: A Human History (New York: Penguin, 2007), esp. 237-8. The purpose of this practice was, as Rediker explains, to provide exercise and fresh air to prisoners kept in appalling conditions.

${ }^{7}$ George Gordon, Lord Byron, Don Juan, II.xii, in Poetical Works, ed. Frederick Page, new ed. corrected by John Jump (London: Oxford University Press, 1970), 662. 
shipboard environments determine human inter-relationships in specific ways, they are also, in some cases, interested in human engagements with the watery world itself - and in how those engagements, often mediated through literary practices, affect and develop seafaring identities. Finally, the following essays indicate some of the ways in which maritime studies can profitably draw on and engage various fields of academic study, including life writing, the histories of reading and of the book, literary criticism, migration and mobility studies, colonial studies, cultural geography, performance studies, environmental history, and oceanic studies (sometimes called the 'Blue Humanities'). Over the remainder of this introduction, we offer a general discussion of some of these historical and academic contexts and outline the approaches taken and the topics engaged by the essays that follow.

\section{HydropHASIA}

Shipboard Literary Cultures participates in a pronounced turn towards the sea across the arts and social sciences over the past two decades. ${ }^{8}$ Such work has often claimed that we live in a culture of 'sea-blindness', or what the literary critic Margaret Cohen, in her groundbreaking book The Novel and the Sea (2010), dubbed 'hydrophasia'-a neglect of the sea. ${ }^{9}$ Although we are more reliant on the sea than ever before in our day-to-day lives, these critics point out, with a huge proportion of global trade carried across the oceans, global communication networks running along the

\footnotetext{
${ }^{8}$ Important studies and collections within what is a diverse field would include Philip Steinberg, The Social Construction of the Ocean (Cambridge: Cambridge University Press, 2001); Bernhard Klein and Gesa Mackenthun (eds), Sea Changes: Historicizing the Ocean (London: Routledge, 2003); Margaret Cohen, The Novel and the Sea (Princeton: Princeton University Press, 2010); John Mack, The Sea: A Cultural History (London: Reaktion, 2011); and Helen M. Rozwadowski, Vast Expanses: A History of the Oceans (London: Reaktion, 2018). Helpful overviews and discussions of the oceanic turn include Steve Mentz, 'Toward a Blue Cultural Studies: The Sea, Maritime Studies, and Early Modern English Literature', Literature Compass 6.5 (2009), 997-1013; Hester Blum, 'The Prospect of Oceanic Studies', PMLA 125.3 (2010), 670-77 and 'Introduction: Oceanic Studies', Atlantic Studies 10.2 (2013), 151-5; and John Gillis, 'The Blue Humanities', Humanities 34.3 (2013). For an essay that approaches 'sea-blindness' from a rather different disciplinary perspective, see Christian Beuger and Tim Edmunds, 'Beyond Seablindness: A New Agenda for Maritime Security Studies', International Affairs 93.6 (2017), 1293-1311. Many other relevant studies will be referenced and engaged over the following pages.

${ }^{9}$ Cohen, Novel and the Sea, 14.
} 
seafloor, and a significant percentage of our energy supply coming from the seabed, we do not feel the oceans in our cultures as we once did. ${ }^{10}$ The mechanization of shipping has meant that maritime culture no longer penetrates cities such as London and New York; instead, vast container ships, with their threadbare crews, pull into port complexes remote from urban life. Even in cities that retain large ports, such as Rotterdam and Los Angeles, far fewer people are directly employed by maritime commerce. Greater efficiencies in the logistics of seaborne trade also mean that sailors no longer stop on shore for weeks on end, bringing with them a taste of the sea; indeed, many of them never leave the ship during stopovers that can be as short as twenty-four hours. The advent (and increased affordability) of air travel, meanwhile, has resulted in far fewer people taking to sea for extended periods of time as a means of crossing the oceans. ${ }^{11}$

Often taking its cue from Fernand Braudel's seminal study of the Mediterranean world, the academy's 'oceanic turn' has resulted in the emergence of several fields focusing on specific ocean basins, including, most prolifically, the Atlantic, the Pacific, and the Indian Ocean. ${ }^{12}$ Such work places a valuable emphasis on connections between cultures-on the mobility of people, ideas, and goods-in a way that has complicated

\footnotetext{
${ }^{10}$ While scholars in literary studies and social history have tended to speak of a 'forgetting' of the sea, human geography scholars argue that, until very recently, the sea has always remained out of sight in their discipline: 'The oceans and seas are entwined, often invisibly but nonetheless importantly, with our everyday lives', write Jon Anderson and Kimberley Peters. 'Trade, tourism, migration, terrorism, and resource exploitation all happen in, at, and across the oceans. The globalized world of the twenty-first century is thus thoroughly dependent upon water worlds. Despite this, geography, as "earth writing" [...] has largely taken its etymological roots seriously $[\ldots]$ The discipline has been a de facto terrestrial study; the sea has not been accorded the status of a "place" worthy of scholarly study'. Anderson and Peters, " "A perfect and absolute blank": Human Geographies of Water Worlds', in Anderson and Peters (eds), Water Worlds: Human Geographies of the Ocean (Farnham: Ashgate, 2014), 3-19.

${ }^{11}$ The popularity of cruises (at least until the Covid-19 pandemic) might seem to buck this trend. Undertaken for pleasure rather than by necessity, however, such journeys are in some respects a further indication of a new phase of human relations with the oceans.

${ }^{12}$ For a critique of the established 'genealogy' of oceanic studies, which aims to show 'how thinkers, narrators and historians have written of the sea beyond the Mediterranean - and, by extension, the Atlantic - over long periods before the rise of US- and Europe-based scholarship on seas', and seeks also to demonstrate how the use of the Mediterranean and Atlantic models can be 'inhibiting' for studies of sites such as the Arctic and the Red Sea, see Armitage, Bashford, and Sivasundaram (eds), Oceanic Histories, 2-3, passim.
} 
nation-based understandings of political and literary cultures. ${ }^{13}$ But as several critics have pointed out, even within such fields there has sometimes been a tendency to lose sight of the sea itself: to focus, as Philip Steinberg complains, on what happens at the 'rim' of ocean basins rather than asking what happens within the rim's circumference. ${ }^{14}$ If there has been a growing acknowledgement of how sea voyages have wired (and still wire) the world in which we live, then it is only more recently that substantial attention has been granted to the networks themselves. ${ }^{15}$

In focusing on what takes place at sea, then, our collection develops scholarship that aims to reveal how shipboard histories have contributed to the landed cultures in which we live. In part, this means considering the experiences of individuals involved in wider historical processes or events: to focus, that is, not on 'heroic' voyagers-Columbus, Magellan, Vasco

${ }^{13}$ Studies of distinct 'ocean worlds' are too numerous to cite here, but (beyond the aforementioned Ocean Histories) an important work that also offers a summary of the field is the AHR Forum on 'Oceans in History' edited by Kären Wigen, which features articles on the Mediterranean, the Atlantic, and the Pacific: American Historical Review 111.3 (2006), 717-80. For especially valuable studies focusing on the Indian Ocean, see Rila Mukherjee, 'Escape from Terracentrism: Writing a Water History', Indian Historical Review 41 (2014), 87-101, and Isabel Hofmeyr, 'The Complicating Sea: The Indian Ocean as Method', Comparative Studies of South Asia, Africa and the Middle East 32.3 (2012), 584-590. As the editors of Oceanic Histories note, one potential weakness of work that stresses the 'transnational' dimension of oceanic history (and one addressed in both Hofmeyr's and Mukherjee's articles) is that it still places too much emphasis on the nation state, where in fact human connections across oceans are usually local in nature: 'Coastal entrepôts operated in a global geography of connection, not with nations or the capitals of other polities, but primarily, even exclusively, with other local port towns' (5).

${ }^{14}$ Philip E. Steinberg, 'Of Other Seas: Metaphors and Materialities in Maritime Regions', Atlantic Studies 10.2 (2013), 156-69. An important exception is the focus on the 'middle passage' of slave and convict transportations; see for instance, Emma Christopher, Cassandra Pybus, and Marcus Rediker (eds), Many Middle Passages: Forced Migration and the Modern World (Berkeley: University of California Press, 2007). As Steinberg complains in 'Of Other Seas', however, even scholarship in this area can sometimes seem to ignore the ocean itself (the example he gives is Paul Gilroy's influential 1993 study The Black Atlantic: Modernity and Double Consciousness [London: Verso, 1993]). Recent work on migration history has also moved towards a focus on voyages, but this body of scholarship remains limited. Examples include David Hastings, Over the Mountains of the Sea: Life on the Migrant Ships 1870-1885 (Auckland: Auckland University Press, 2006); Katherine Foxhall, Health, Medicine and the Sea: Australian Voyages, c. 1815-1860 (Manchester: Manchester University Press, 2012); and Stephen R. Berry, A Path in the Mighty Waters: Shipboard Life \& Atlantic Crossings to the New World (New Haven: Yale University Press, 2015).

${ }^{15}$ For a fascinating film essay examining such networks and their implications, see Allan Sekula and Noël Burch's The Forgotten Space (2010). 
Da Gama-whose storied journeys marked out new routes and dramatically reshaped global networks, but rather on the figures who followed in their wake or who explored uncharted waters in a less spectacular manner. Jimmy Packham's essay, for example, examines diaries composed on American whaleships, offering a window on the strange day-to-day existence of two individuals - one a professional of over thirty years' experience, the other a young girl on her father's ship-involved in an industry that was crucial in driving both the economy and the geographical and scientific knowledge-making of the United States of America in the nineteenth century. Susann Liebich's essay, meanwhile, enriches our understanding of World War I combatants by analysing newspapers produced on troop transports ferrying soldiers from New Zealand to England and Egypt, while Helen Chambers's essay takes us aboard several voyages of a single ship which, by carrying Europeans in the opposite direction-and to Australia-participated in a pattern of migration that shaped the Pacific world as we now know it.

Where Chambers's essay deals with the experiences of relatively highstatus emigrants, Tamsin Badcoe's introduces us to a more diverse group of seafarers travelling along the same route aboard the SS Great Britain; her essay examines the diary of a nun leaving Ireland to offer a Catholic education to children in the colony of Victoria at a time when state support had been removed from denominational schools. In this sense, Badcoe's essay not only provides insight into the lived experience aboard one of the most celebrated ships of its age, but also explores a personal testimony that is integrated into a wider history of education in Australia. David Punter's Afterword (Chap. 11), meanwhile, offers reflections on the experiences of the sailors who crew the contemporary container ships whose voyages underpin global capitalism. To shift the metaphor a little: by exploring the experiences of those aboard ships, we gain a richer understanding of the cogs in the machine that produces global history. ${ }^{16}$

\section{WRITING AT SEA}

While sometimes considering how individual lives feed into and are coloured by national and global histories, however, for the most part our contributors are concerned with the experience of being at sea-and,

\footnotetext{
${ }^{16}$ Roland Wenzlhuemer and Martin Dusinberre make a similar point in 'Editorial - Being in Transit: Ships and Global Incompatibilities', Journal of Global History 11 (2016), 1-8.
} 
more specifically, with the literary activities that shape maritime experience, and which are themselves ocean-stained.

For the historian of shipboard literary cultures, perhaps the most important textual genre is the diary (or 'journal'-we use the terms interchangeably), not least because diaries are often the medium through which we learn about other forms of literary activity. ${ }^{17}$ The greatest age of Anglophone seafaring - the long nineteenth century-came at a time when the manufacture of cheaper paper made keeping a private diary feasible for a much greater proportion of those who took to the oceans. ${ }^{18} \mathrm{It}$ also coincided with a significant rise in the popularity of diary-writing across Europe. According to Peter Burke, this rise can be linked to broader historical phenomena: a shift in individuals' attitudes towards their pasts (and towards the past in general), and developments in notions of the self that placed 'a greater stress on sincerity, authenticity, uniqueness, intimacy, self-discovery and so on'. ${ }^{19}$ These processes of 'historicizing the self' from the late eighteenth century onwards led to new expectations in terms of the functions of diaries, which increasingly became a means for accounting for time and for facilitating and observing individual 'development' within a 'constructible' future. ${ }^{20}$

In combination, these cultural and historical developments have afforded maritime historians a far fuller record of life at sea on Anglophone vessels of the long nineteenth century than exists for earlier periods. While

${ }^{17}$ On the usefulness of diaries and other egodocuments for investigating historical reading practices, see, for example, Stephen Colclough, 'Recovering the Reader: Commonplace Books and Diaries as Sources of Reading Experience', Publishing History 44 (1998), 5-37.

${ }^{18}$ Jeremy D. Popkin, 'Philippe Lejeune, Explorer of the Diary', in Philippe Lejeune, On Diary, ed. Popkin and Julie Rak, trans. Katherine Durnin (Honolulu: University of Hawai'i Press, 2009), 1-15 (7). The tradition of keeping an account of a voyage has a longer history among more privileged seafarers, however. In his essay 'Of Travel', Francis Bacon complains: 'It is a strange thing, that in sea voyages, where there is nothing to be seen but sky and sea, men should make diaries; but in land-travel, wherein so much is to be observed, for the most part they omit it' (The Major Works, ed. Brian Vickers [Oxford: Oxford University Press, 1996], 374-6 [374]). One of the purposes of this volume is to try to understand the phenomenon to which Bacon points.

${ }^{19}$ Peter Burke, 'Historicizing the Self, 1770-1830', in Arianne Baggerman (ed.), Controlling Time and Shaping the Self: Developments in Autobiographical Writing Since the Sixteenth Century (Leiden: Brill, 2011), 13-32 (13, 16).

${ }^{20}$ Burke refers to Reinhard Koselleck's argument about new ideas of the future as open and constructible developing in the wake of the French Revolution. Reinhard Koselleck, 'Historia Magistra Vitae: Über die Auflösung des Topos im Horizont neuzeitlich bewegter Geschichte', in Koselleck, Vergangene Zukunft: Zur Semantik geschichtlicher Zeiten (Frankfurt: Suhrkamp, 1979), 38-66, cited in Burke, 14. 
manifests and logbooks provide information on whom or what a ship carried, where it went, and what major incidents befell it, journals and diaries offer more vivid, detailed, and emotionally rich accounts of these matters. They do not, however, tend to offer as much in the way of intimate selfreflection as we might expect, given Burke's remarks on the diary's role in the development of 'self-discovery'. ${ }^{21}$ There are specific reasons for this. First, many nineteenth-century migrants recorded their journeys with the intention of sending either their diary or a fair copy of it back across the sea to concerned friends or family; for obvious reasons, such documents tend to avoid the more private reflections and confessions that characterize other forms of private autobiography. Thus disseminated, these diaries would have created patterns for subsequent seafarers to follow. And second, while extending and elaborating on material committed to logbooks, shipboard diaries are nonetheless intrinsically linked to that textual form. ${ }^{22}$ Rather than recording private confessions (in the manner that other theorists of the rise of the diary have linked to Protestant practices), shipboard diaries tend, like the logbook, to record 'remarkable' incidents.

Diary-writing also provided seafarers with occupation during what was often a monotonous period. There is a paradox here: shipboard diaries are kept because the author feels that going to sea is sufficiently 'eventful' to warrant recording; at the same time, the relative lack of events to record frequently finds the diarist apologizing for having nothing of interest to say. This lack of variety can lead in two directions: either to a lack of entries (or very brief ones acknowledging that nothing remarkable occurred on the day in question) or to a turn 'inward', as the lack of events-which in practice often means calm seas, and thus relatively easy conditions for writing-prompts a diarist to offer character sketches of their fellow seafarers, or, in some cases, broader political or philosophical remarks that are generated through observations on the quotidian events of shipboard life. On

${ }^{21}$ There are exceptions, of course, as some of the essays that follow indicate.

${ }^{22}$ To some extent, this may be true of diaries more generally: Philippe Lejeune has linked the development of the diary 'to the spread of other modern cultural practices, such as bookkeeping, that rationalized [...] forms of memory'. Popkin, 'Philippe Lejeune', 7. See also Rudolf Dekker, 'Introduction', in Dekker (ed.), Egodocuments and History: Autobiographical Writing in Its Social Context since the Middle Ages (Hilversum: Verloren, 2002), 7-20; Kathryn Carter, 'Accounting for Time in Nineteenth-Century Manuscript Diaries and Photographs', Life Writing 12.4 (2015), 417-430; and Katie Holmes, 'Marking Time: Australian Women's Diaries of the 1920s and 1930s', in Baggerman (ed.), Controlling Time and Shaping the Self, 169-196. 
some occasions, then, it is relative inactivity that prompts-or that allows for-the act of writing at sea. ${ }^{23}$

For the most part, however, shipboard diaries record motion: and if all diaries mark progress through time, then shipboard diaries are notable also for their charting of space. Indeed, many diarists-again in imitation of the ship's log-included coordinates of latitude and longitude and the length of the ship's 'run' in their daily entries. And, as several of our contributors argue, diaries did not only chronicle voyages; they also shaped the ways in which their authors experienced those voyages. The physical diary, with its limited and bounded pages, offered the promise that the voyage would stay within certain parameters, with individual entries traversing its pages in a manner that traced the vessel's progression through the water. ${ }^{24}$ In his study of migrants' journeys to Australia, Andrew Hassam argues that shipboard diaries 'actively contributed towards the way in which the voyage out was lived' ${ }^{25}$ For Hassam, 'it was the act of recording that was important, and if the diaries have been passed down in a way that makes them seem inevitable and finished artefacts, we nonetheless have to attempt to guess not so much why they were written, but what the effect of their being written was on the writer'. ${ }^{26}$ Chapters 5,6 , and 7 in the present volume examine how the diaries of inexperienced seafarers helped their authors orient themselves within the maritime world, in part through the very act of imitating the language and form of the ship's log.

Professional mariners, too, kept diaries as a means of orienting themselves - and, in their case, of developing their professional knowledge and identity. But they may also have had more directly economic reasons for recording their experiences. As Margaret Cohen and others have

${ }^{23}$ In a study of the seventeenth-century English seafarer Edward Barlow, Steve Mentz notes that it was immobility - 'nearly a year floating perfectly still' — that prompted Barlow to begin writing his 'massive journal' (Shipwreck Modernity: Ecologies of Globalization, 1550-1719 [Minneapolis and London: University of Minnesota Press, 2015], 103). For further reflections on the practicalities of and motivations for writing at sea, and also on 'literary' constructions of ocean-going experiences (especially within a nineteenth-century scientific context), see also Helen M. Rozwadowski, Fathoming the Ocean: The Discovery and Exploration of the Deep Sea (Cambridge, Mass.: Harvard University Press, 2005), esp. 19-28, 204-5.

${ }^{24}$ The use of margins towards the ends of voyages does, however, suggest that not all diarists judged the length of the voyage correctly.

${ }^{25}$ Andrew Hassam, Sailing to Australia: Shipboard Diaries by Nineteenth-Century British Emigrants (Manchester: Manchester University Press, 1994), 1.

${ }^{26}$ Hassam, Sailing to Australia, 2. 
demonstrated, non-fiction accounts of life at sea had a significant presence in the French and Anglo-American publishing worlds of the eighteenth and nineteenth centuries, existing in a complex dynamic with sea fiction by authors including Daniel Defoe, Victor Hugo, and James Fenimore Cooper. ${ }^{27}$ Sailors' diaries may therefore contain traces of literary ambition and financial opportunism. ${ }^{28}$ These differing reasons for keeping a diary, then, offer an initial example of how shipboard literary cultures are determined by the specific identity and role of the seafarer.

It is also worth thinking about our reception of such documents. Reflecting on and citing the work of Philippe Lejeune, perhaps the foremost scholar of autobiography, Jeremy D. Popkin has argued that "the attraction of reading a diary is based on "the feeling of touching time," a sensation that can only be generated if we sense that the diary author was recording his or her real experiences and thoughts' ${ }^{29}$ While we may have reservations as to the prospect of recovering a diarist's 'real thoughts', especially in the context of shipboard diaries which generally lack private ruminations, such documents undoubtedly possess a quality that cannot be replicated in fictionalized narratives - or even in non-fictional accounts 'written up' at a later date, such as Richard Henry Dana's Two Years Before the Mast (1840), the celebrated and influential account of an educated young American who took to sea as a common sailor in the nineteenth century. Towards the conclusion of Chap. 5, Eli Cumings and Laurence Publicover reflect on the ways in which the material diary composed at sea allows us to 'touch place' (slightly to alter Lejeune's expression): to sense, in otherwise unrecoverable ways, what it meant for authors to be at sea and to record and process that experience. An initial example of this peculiar quality of the manuscript shipboard diary can, in fact, be provided by the passage with which this introduction began. Edward Beck's maritime writings have been collected in a modern edition that renders the passage thus:

${ }^{27}$ Cohen, Novel and the Sea, 5-9. As Cohen also notes, one of the abiding topics of sea fiction is the 'practical skills of oceangoing adventurers' (2); many novels set at sea concern themselves with a protagonist's incremental mastery of such skills: a process also captured in shipboard diaries and other texts composed by professional seafarers.

${ }^{28}$ As Packham discusses in his contribution to this volume, it was not only written accounts, but also sketches (sometimes featured within such accounts) and carvings, that found a market back on land in the nineteenth century.

${ }^{29}$ Popkin, 'Philippe Lejeune', 9. 
They play in the water much like porpoises, and are in their native element.

I had written this when the vessel shipped a bit of sea and the spray, flying over my book, obliges me [to] leave writing till it is again dry. ${ }^{30}$

This text certainly captures something of the experience of writing at sea. But if we compare it with the image above (Fig. 1.1), and note its eliding not only of the diary's occluded text, but also the ocean-created blemish itself, then we must feel that it lacks the stain of the sea in the fullest sense.

\section{Performing at Sea}

If handling diaries composed at sea-and examining the feathers, menus, and other paraphernalia often tucked inside their pages - provides us with extraordinary access to the lived experience of a voyage, then another form of shipboard literary culture, dramatic performance, cannot be so readily accessed. But while the performances (and usually the play-texts beneath them) are unrecoverable, tantalizing traces in the archives-perhaps the most famous of which concerns a possible performance of Shakespeare's Hamlet on board an East India Company vessel off the coast of West Africa during its 1607-10 voyage-hint at the extent and significance of shipboard theatricals. ${ }^{31}$

There is, in fact, something inherently theatrical in shipboard life: like theatres, ships are full of recesses, entrances, and exits, and they also feature stage-like spaces - the quarterdeck, the poop deck-on which individuals perform specific roles; as several commentators have noted, there are intriguing connections to be made between the wooden theatres of early modern London, which presented the globe to audiences thirsty for knowledge of it, and the wooden ships through which England explored and began to exploit that world. ${ }^{32}$ More directly relevant to our purposes,

${ }^{30}$ Kenneth M. Hay and Joy Roberts (eds), The Sea Voyages of Edward Beck in the 1820s (Durham: The Pentland Press, 1996), 57.

${ }^{31}$ For a recent summary of and intervention in the long-running debate regarding the authenticity of the documents purporting to record these performances, see Richmond Barbour and Bernhard Klein, 'Drama at Sea: A New Look at Shakespeare on the Dragon', in Claire Jowitt and David McInnis (eds), Travel and Drama in Early Modern England: The Journeying Play (Cambridge: Cambridge University Press, 2018), 150-168.

${ }^{32}$ See, for example, Douglas Bruster, 'Local Tempest: Shakespeare and the Work of the Early Modern Playhouse', in Patrick M. Murphy (ed.), The Tempest: Critical Essays (London: Routledge, 2001), 257-275 (260-2). 
however, and specifically to Mary Isbell's essay in this volume, is how the everyday 'theatricality' of shipboard life was distilled into more formal performances - sometimes of famous plays (or adaptations of them), but often of plays composed on board, some of which reflected the life of the ship back to itself. Such performances were often designed to raise morale and strengthen communal bonds on long and difficult voyages. Indeed, they were especially valuable when ships became static-during ice-bound periods in voyages of polar exploration, for example, or when at anchor during a military campaign. ${ }^{33}$

Performances at sea, like other cultural practices, also indicate active attempts to bring elements of a 'landed' past to the ship, or at least highlight how such elements shaped, even unintentionally, shipboard activities. Programmes produced for specific events jokingly liken the ship to Covent Garden, and performances organized by a ship's officer class often come across as a development of activities first undertaken at elite private schools. The most common form of 'performance' that reminded seafarers of their shore lives, however, was perhaps the religious ceremony, an activity which also helped to mark time during a voyage. Like scripted theatricals and musicals, such ceremonies had the potential to divide as well as unite a ship's company; as Badcoe's essay in this volume indicates, a multi-faith shipboard community such as that of the SS Great Britain on its Australian voyages was often fraught with tensions generated by religious difference, and such tensions could be exacerbated by the performance of religious rites.

\section{ReAding AND THE SEA}

For reasons we shall discuss more fully below, going to sea can be an immensely disorienting experience; and in this context, activities that remind individuals of their shore identities, whether these be religious rituals, performances of well-known plays, the re-reading of books first encountered on land, or even the act of writing ' $\mathrm{I}$ ' in a diary, become immensely powerful. Previous experiences of reading also create a bridge between sea and land. Shipboard diaries appear unusually prone to quotation, as though diarists feel a need to structure their novel experiences

${ }^{33}$ See, for example, Hester Blum, The News from the Ends of the Earth: The Print Culture of Polar Exploration (Durham, NC: Duke University Press, 2019); Elizabeth Leane, South Pole: Nature and Culture (London: Reaktion, 2016). 
through prior reading. Chapter 6 of this volume opens with a discussion of a nineteenth-century American whaler who, it appears, interpreted his voyage through the lens of classical literature encountered during his schooldays. In other instances, diarists test their present experiences against literary representations of the sea. Edward Beck, for example, reveals dissatisfaction with a well-known poem in which a vessel moves over a sea so calm that it resembles a 'silver lake'.

There is a great mistake in this description of a calm, which we must excuse in a poet that is no sailor; I mean in that line which says, 'And o'er the calm the vessel glides', because it is well known she moves none without wind except in a tide, and then I conceive she only moves with it, and not over it. ${ }^{34}$

Samuel Taylor Coleridge's poem The Rime of the Ancient Mariner (1798, 1817) is, perhaps unsurprisingly, a common sea-mark for nineteenthcentury Anglophone seafarers. ${ }^{35}$ But diarists refer to a range of poetry, and also to narrative fiction and Bible passages, often in an attempt more eloquently to express their emotional experiences or describe their environments. ${ }^{36}$ The Afterword (Chap. 11) to this volume reflects on this textual sedimentation, considering how literary narratives and their consumption not only transmitted, but also shaped the cumulation (in the now) of a collected and constructed cultural memory of experiencing the sea. In fact, this body of sea literature is occasionally what sends individuals to sea in the first place - or at least, there are several fictional representations of this phenomenon. ${ }^{37}$ The title character of Lord Jim (1899) — a novel by the sailor-turned-author Joseph Conrad, who features in this collection primarily as first mate on the Torrens-develops a 'vocation for the sea' after reading 'light holiday literature' ${ }^{38}$ In Malcolm Lowry's thinly veiled autobiography Ultramarine (1933), the protagonist, filled with dreams of

\footnotetext{
${ }^{34}$ Hay and Roberts (eds), The Sea Voyages of Edward Beck, 58. The poem Beck slightly misquotes is by Thomas Moore (1779-1852).

${ }^{35}$ Widespread knowledge of this poem does not appear to have prevented seafarers from shooting albatross, however.

${ }^{36}$ In the passage cited below, for example, Dana echoes Coleridge's poem in his reference to a 'wide, wide sea'.

${ }^{37}$ For further discussion of this phenomenon, see Rozwadowski, Vast Expanses, 125.

${ }^{38}$ Joseph Conrad, Lord Jim: A Tale, ed. Allan H. Simmons (London: Penguin Classics, 2007), 7.
} 
the sea, is tellingly named 'Dana', recalling the author of the alluring Two Years Before the Mast. ${ }^{39}$

The relations between reading and the sea are, then, complex and multi-faceted. For the most part, however, the following essays are concerned less with what seafarers have read back on land than with what they choose - or are able - to read at sea. As Conrad's and Lowry's fictional characters quickly discover, being at sea is not quite the romantic, exhilarating experience it is sometimes cracked up to be; it can be extremely monotonous, and it provides the seafarer with an enormous amount of time to fill. Despite its 'entertainments', even the modern cruise ship can become extraordinarily tedious in its repetitive nature-a fact brilliantly rendered in David Foster Wallace's essay 'A Supposedly Fun Thing I'll Never Do Again', discussed in the Afterword (Chap. 11)-and for centuries shipboard life has generated a craving for reading matter. ${ }^{40}$ Jonathan Swift, who himself crossed the Irish Sea many times, has his fictional ship's surgeon Lemuel Gulliver relate of his early years at sea: 'My Hours of Leisure I spent in reading the best Authors, ancient and modern; being always provided with a good Number of Books' ${ }^{41}$ In addition to improving themselves with great works of literature, passengers on long voyages of migration spent their transit reading self-help literature and emigration guides. ${ }^{42}$ Letters and newspapers were just as welcome, and there was often excitement when, in mid-ocean, one ship met another in order to 'speak' it (as the maritime idiom had it), allowing for the exchange of such materials: in this sense, texts can circulate not only within ships, but also between ships in mid-ocean. And as Bill Bell notes, for migrants en route

${ }^{39}$ Lowry revisits this territory in his most famous work, Under the Volcano (1947); on this occasion, it is the hero's younger brother, Hugh Firmin, who has been lured to sea by such accounts.

${ }^{40}$ David Foster Wallace published 'Shipping Out', an essay describing his experience on a week-long Caribbean cruise, in Harper's Magazine in 1996. It was reprinted as the title piece in the collection A Supposedly Fun Thing I'll Never Do Again: Essays and Arguments (London: Little, Brown, 1997).

${ }^{41}$ Jonathan Swift, Gulliver's Travels, ed. Claude Rawson (Oxford: Oxford University Press, $2005), 16$.

${ }^{42} \mathrm{On}$ the popularity of emigration guides in the nineteenth century, see Bill Bell, 'Print Culture in Exile: the Scottish Emigrant Reader in the Nineteenth Century,' Papers of the Bibliographical Society of Canada 36.2 (1998), 87-106, and Simon Frost, 'A Trade in Desires: Emigration, A.C. Gunter and the Home Publishing Company', in Nicola Wilson (ed.), The Book World: Selling and Distributing Literature, 1900-1940 (Leiden: Brill, 2016), 31-51. 
to Australia in the nineteenth century 'one of the most popular shipboard entertainments [was] reading aloud', an activity that shades into the modes of performance outlined above. ${ }^{43}$

Professional seafarers have much less time to themselves, and historically they have needed to spend at least some of it on tasks such as mending clothing; but until the age of the video and DVD, sailors on days of rest-usually Sundays in the Anglophone world-were often found with book in hand. This aroused the interest of those who saw themselves as moral guardians; as Hester Blum has demonstrated, 'sailors' reading practices became an explicit target of reform movements in the 1820s and 1830s, which were particularly concerned with raising literacy rates and promoting Bible reading among seamen'. ${ }^{44}$ But there was, Blum notes, a gap between what sailors were supposed to read and what they wanted to read: they 'benefited from these religious and secular reform movements to a great extent but affirmed their literary preference for the Pirates Own Book, say, over pious tracts'. ${ }^{45}$ As Stephen Berry explains in Chap. 3, the sea has often been regarded as a site of moral degeneracy; but his contribution to this volume-like those by Helen Chambers, Tamson Pietsch, Christian Algar, and Tamsin Badcoe-also demonstrates how, in specific circumstances, the ship could become a site of education. And as all these essays demonstrate, books and their uses shaped shipboard environments in particular ways.

${ }^{43}$ Bill Bell, 'Bound for Australia: Shipboard Reading in the Nineteenth Century', Journal of Australian Studies 25.68 (2001), 5-18 (17); see also Bell, 'Print Culture in Exile'.

${ }^{44}$ Hester Blum, The View from the Masthead: Maritime Imagination and Antebellum American Sea Narratives (Chapel Hill: University of North Carolina Press, 2008), 5. See also Harry R. Skallerup, Books Afloat \& Ashore: A History of Books, Libraries, and Reading Among Seamen During the Age of Sail (Hamden: Archon Books, 1974), esp. 77-88; and David M. Hovde, 'Benevolence at Sea: Shipboard Libraries for the American Navy and Merchant Navy', in Robert S. Freeman and David M. Hovde (eds), Libraries to the People: Histories of Outreach (Jefferson: McFarlane \& Company, 2003), 50-72.

${ }^{45}$ Blum, View from the Masthead, 5. Blum goes on to note that 'To counter the appeal of such ephemera [as pamphlet novels, ballads, chanteys, broadsides, etc.], benevolent associations advocated the sponsorship of shipboard libraries as well as portside seamen's reading rooms. In promoting the Sailor's Reading Room, for instance, the Seaman's Friend Society recommended stocking the free library with "History, Biography, Voyages, and Travels, and any others that are good and true." A religious magazine for seamen called The Life Boat, in another example, lamented the presence aboard one ship of a young sailor who was "a constant reader, but rather obstinate in his adherence to the light trash in the form of cheap literature which floods our lands, and is generally found in our forecastle, and often in the cabin also"' (5). 


\section{Shipboard Hierarchies and Literary Culture}

Ships are environments marked by an unusually rigid and sophisticated hierarchy. In his study of professional seafarers of the Anglo-American world of the first half of the eighteenth century, Marcus Rediker writes that shipboard labour

meant virtual incarceration, as the seaman was forcibly assimilated into a severe shipboard regimen of despotic authority, discipline, and control. Shipboard life constituted a binding chain of linked limits: limited space, limited freedom, limited sensory stimulation, and limited choice of leisure activities, social interaction, food, and play. ${ }^{46}$

The relative lack of space on a ship encourages strict definition of specific places; a relatively undifferentiated ocean beyond the bounds of the ship produces a highly differentiated space within it, not least because the negotiation of the dangerous ocean requires clearly defined duties and chains of command. This well-ordered structure is, as Rediker suggests, connected to other forms of regimentation experienced by the common sailor-a phenomenon also discussed by Greg Dening in his study of the Bounty mutiny of 1789:

The boundaries [on the Bounty] were not just between quarterdeck and lower deck $[\ldots]$ They were between messes, watches, divisions, between foremast, main-mast, and mizzenmast men, between waisters and topmen, between aftergard and fo'c'sle, to say nothing of all the distinct functionaries between captain and boy and all their mates. Daily life was full of plays and gestures that marked status and privilege, that established group and subgroup existence, that drew and redrew boundaries according to the needs of maintaining the ship. ${ }^{47}$

${ }^{46}$ Marcus Rediker, Between the Devil and the Deep Blue Sea: Merchant Seamen, Pirates, and the Anglo-American Maritime World, 1700-1750 (Cambridge: Cambridge University Press, 1987), 159. The 'incarceration' (to borrow Rediker's term) experienced by those on ships links the study of shipboard literary culture to another emerging field, 'prison writing' or 'prison literature'. Samuel Johnson is perhaps the most famous of many figures to have likened going to sea to going to prison: see Marshall Waingrow (ed.), James Boswell's Life of Johnson: An Edition of the Original Manuscript, Vol. I: 1709-1765 (Edinburgh, New Haven and London: Edinburgh University Press and Yale University Press, 1996), 244.

${ }^{47}$ Greg Dening, Mr Bligh's Bad Language (Cambridge: Cambridge University Press, 2010), 81-2. 
If being 'at sea' unsettles personal identity, as we shall argue below, then shipboard life does much to put the self into bounds, with distinct spaces clearly demarcating who you are, or at least what is required of you. There is, as we have noted, and as Dening also observes, something distinctly theatrical about the ship: aboard, one performs a particular role on specific stages. In a professional context, if one performs well in one sphere one might then graduate into another, with a new set of spatial and social privileges; but one would still exist within a system that is, as Dening explains, extremely detailed in the roles it demarcates and in how space is structured in relation to those roles. Boundaries may be drawn and redrawn, but they are always important.

Of course, not all ships were as regimented as those of the British and American navies of the eighteenth century. But almost all vessels that spend a significant period at sea are characterized by a careful structuring of space, time, and role: by divisions between crew and non-crew, and by further distinctions within those groups. On vessels as diverse as nineteenthcentury navy vessels and contemporary cruise ships, cultural rituals signal social standing. Sitting at the table of the captain-typically the all-powerful monarch of the ship's little world-is a sign of privilege; on the SS Great Britain, lines drawn on deck marked out space accessible only to the most privileged passengers. One of the things that makes Sister Mulquin, the subject of Badcoe's essay in this volume, such an interesting figure is that her religious calling allowed her access to numerous parts of a vessel that, for the most part, carefully segregated its inhabitants. Her experience reminds us, once again, that the geographies of ships are constantly in flux, defined and redefined in relation to social practices and expectations. ${ }^{48}$

One of the principal aims of this collection is to demonstrate how reading, writing, and performing both created and disturbed shipboard hierarchies. An initial example can be found in perhaps the most notorious and widespread performance-cum-ritual on Anglo-American ships of the modern period, the 'crossing the line' ceremony. This event, discussed in

\footnotetext{
${ }^{48}$ The geographer Doreen Massey has been most influential in stressing how places and spaces are social constructs, open and constantly being made through links to other places, with the global always present in the local. Beyond that, Massey asserts that space entails the possibility of multiplicity 'in the sense of contemporaneous plurality'; and it 'is always in the process of being made'. Doreen Massey, For Space (London: SAGE, 2005), 9-11, 107-19. See also the foundational text on the notion of space as a social construct: Henri Lefebvre, The Production of Space, trans. Donald Nicholson-Smith (Oxford: Blackwell, 1991 [1974]). On the geography of ships, see William Hasty and Kimberley Peters, 'The Ship in Geography and the Geographies of Ships', History Compass 6.11 (2012), 660-676.
} 
detail in Chap. 4, saw sailors who had not previously crossed the equator initiated into the Kingdom of Neptune-with varying degrees of violence and good humour-by those shipmates who had. Those initiated would often include junior officers outranking those who masterminded the performance. By temporarily inverting (or at least partially inverting) the crew's hierarchy, by its conclusion the ritual strengthened the bond between shipmates: something aided, in many cases, by the tattooing of the 'hazed' sailors. On some vessels, the event also allowed for an unusual degree of interaction between crew and passengers; the latter, in the age of sail and in an Atlantic context, were only too glad of a distraction as the ship passed through the sweaty and tedious 'Doldrums'. Indeed, if the length of entries in shipboard diaries is anything to go by, crossing the line was for passengers usually one of the highlights of the voyage: even those who disapproved often wrote about it at length. Providing a spectacle that brought them into contact with 'maritime' life, it allowed them to feel that they, too, were entering Neptune's kingdom.

A less spectacular example of how cultural activities could forge a sense of community can be found in a literary phenomenon not yet mentioned: the production of a shipboard newspaper. This form of text, discussed at length in Susann Liebich's contribution to this volume, but also featuring in Isbell's and Pietsch's essays, often contained reviews of onboard performances of various kinds and informed seafarers in advance of onboard events. For these reasons, and because it provided a chronicle of the voyage, the shipboard newspaper had the potential to create a sense of shared experience. This was the case not only on passenger vessels, but also on military ships, as Liebich's essay indicates. As Johanna Beamish has demonstrated, however, shipboard newspapers also provide evidence of, and could in some cases contribute towards, conflicts between opposing communities on board: their columns offered the space to argue and to create boundaries and distance between groups of passengers. ${ }^{49}$ Occasionally on migrant vessels, and also on the naval vessels and soldier troopships explored by Liebich and Isbell, passengers travelling in different classes, and crew and soldiers belonging to different groups, produced competing shipboard papers. In such instances, print could become a means of expressing alternative concerns and viewpoints, and of claiming authority over the formulation of seaborne experiences.

\footnotetext{
${ }^{49}$ Johanna de Schmidt, "“This strange little floating world of ours”: Shipboard Periodicals and Community-building in the "Global" Nineteenth Century', Journal of Global History 11 (2016), 229-250.
} 
Like newspapers, dramatic and musical performances had the potential either to strengthen or to weaken shipboard hierarchies. Performances designed exclusively for elite passengers might further exacerbate gaps between privileged and less-privileged shipmates; but as Chambers's contribution to this volume notes, performances of various kinds on the Torrens instead gathered into one place members of a shipboard community that would ordinarily be more strictly segregated. On the other hand, and as Isbell's essay indicates, the mingling of different elements of a ship's company effected by a performance could also cause conflict, driving apart rather than fusing factions. Reading could have similar effects. While new books and reading materials could be picked up in ports or, occasionally, when meeting other ships in mid-ocean, the range and quantity of printed matter circulating on vessels on long voyages was generally limited to what seafarers brought with them-and, on some occasions, the collections of onboard libraries. This limited stock encouraged not only the sharing of such materials but also the discussion of them. ${ }^{50}$ Reading might, then, reconfirm 'horizontal' relations between those on board, with 'reading groups' taking place in particular areas of the ship reserved for specific kinds of seafarer; but it could also establish 'vertical' relations if, for example, a cabin passenger lent a volume to a member of the crew (something recorded in Chambers's essay). Chapter 2 of this volume argues that the possession and circulation of books by a naval chaplain during the English Civil War might have destabilized shipboard hierarchy, creating a form of authority to rival that of the captain. Considering such instances enables us to appreciate, once again, that shipboard life is far from static in its structures; instead, it can be reshaped by various social practices, including literary activities. ${ }^{51}$ In addition, practices established aboard specific kinds of vessels can change over time. As Blum notes, for example, libraries on American naval ships began as communal spaces in which men of different rank would have the chance to interact with one another, but they were

\footnotetext{
${ }^{50}$ On passengers aboard late nineteenth-century steamers lending books to each other, see also Susann Liebich, 'A Sea of Fiction: The Libraries of Trans-Pacific Steamships at the Turn of the Twentieth Century', The Library 20.1 (2019), 3-28.

${ }^{51}$ Marcus Rediker makes a similar point regarding maritime 'culture' in the broader sense: 'The formative influences upon maritime culture were essentially threefold: the nature, conditions, and social relations of work; the physical setting of the ship; and the social characteristics of the producers. Maritime culture was not static, but rather developed over time in response to changes in work, the workplace, and the nature of the workers themselves. Maritime culture was continually formed and reformed within the wooden world' (Between the Devil and the Deep Blue Sea, 198-9).
} 
later co-opted into a more strictly hierarchized system in which enlisted men had borrowing privileges different from those of officers. ${ }^{52}$

\section{BEING AT SEA}

Formations and reformations of social hierarchy took place within an environment which placed personal identity under unusual pressure. This was the case not only due to the discomfort of travel and the risk of disease and drowning (significant though those often were); more than this, and as the English idiom 'all at sea' suggests, leaving the land means jettisoning some of the ways in which humans construct themselves as selves. In his classic study Space and Place, Yi-Fu Tuan argued that 'the built environment clarifies social roles and relations', as people 'know better who they are and how they ought to behave when the arena is humanly designed, rather than nature's raw stage' ${ }^{53}$ His fellow geographer Edward Relph took the point further, arguing that there is a basic human need for geographical attachment, and that from it develops our ethical outlook: 'To have roots in a place', Relph claimed, 'is to have a secure position from which to look out on the world, a firm grasp of one's own position in the order of things, and a spiritual and psychological attachment to somewhere in particular'. ${ }^{54}$

When offering such arguments, neither Tuan nor Relph were thinking specifically of the sea. But their remarks on the importance of 'roots' and on the role of the built environment in human self-constitution can help us understand why spending extended periods of time out of sight of land could be a distressing and unsettling experience, especially for first-time seafarers. The mobile sea, a constantly shifting environment through which ships themselves move, is not a place in which one can put down 'roots' or gain a 'stable' perspective on the world; indeed, in Western culture it has often been considered a site of chaos against which the order of land can be measured. ${ }^{55}$ In this respect, to look out onto a mobile sea while also moving across it might be to lose a sense of one's place in (and

${ }^{52}$ Blum, View from the Masthead, 34.

${ }^{53}$ Yi-Fu Tuan, Space and Place: The Perspective of Experience (Minneapolis: University of Minnesota Press, 1977), 102.

${ }^{54}$ Edward Relph, Place and Placelessness (London: Pion, 1976), 38.

${ }^{55}$ See, for example, John R. Gillis, Islands of the Mind: How the Human Imagination Created the Atlantic World (Basingstoke: Palgrave Macmillan, 2004), esp. 3-6. Similarly, Robert Foulke notes that the oceanic 'environment contains in its restless motion luring possibilities of total disorientation'. Robert Foulke, The Sea Voyage Narrative (New York: Routledge, 1997), 9. 
even one's grasp of) the 'order of things', while the vast expanse of an open ocean-'nature's raw stage'-could trouble a seafarer's sense of themselves. ${ }^{56}$ In Moby-Dick, Herman Melville's narrator Ishmael speaks of the 'awful lonesomeness' of swimming in the open ocean, even when near a ship: 'The intense concentration of self in the middle of such a heartless immensity, my God! who can tell it?' 57 The ocean is here 'heartless' not only in its lack of compassion for human life, but also in being apparently without a centre - a point from which orientation can begin.

If the development and maintenance of identity depends, as Tuan argues, on interactions with a built environment, then being at sea, a site that generally lacks such markers, can result in a turning inward that destabilizes the self. In the chapter of Moby-Dick from which the above quotation is taken, Pip, the Pequod's ship-keeper, descends into madness after being left for a period on the open ocean; and as Angela McCarthy has revealed, migrants on long sea voyages frequently suffered similar disturbances, even while remaining within the bounds of their ships. ${ }^{58}$ The acute sense of isolation and distance from loved ones, so common for seafarers, is one of the main causes of mental distress at sea. A paper at the 2019 Seafarers International Research Centre Symposium argued that the best

\footnotetext{
${ }^{56}$ There are important gradations here: Stephanie Smallwood aptly calls the slave ship 'a place of unparalleled displacement': Saltwater Slavery: A Middle Passage from African to American Diaspora (Cambridge: Harvard University Press, 2007), 13. Also relevant here is the sense (common to many cultures) of the sea as not only fundamentally inhospitable to humans but a site where humans should not be. As the editors of Oceanic Histories note, 'To venture onto the ocean has long been seen as somehow unnatural, with shipwreck and drowning the fitting rewards for hubris in contravening our terrestrial destiny' (8). For an excellent study of this attitude as it plays out in an English Renaissance culture indebted to classical Rome, see Philip Edwards, Sea-Mark: The Metaphorical Voyage, Spenser to Milton (Liverpool: Liverpool University Press, 1997).

${ }^{57}$ Herman Melville, Moby-Dick, ed. Toby Tanner (Oxford: Oxford University Press, 1998), 371.

${ }^{58}$ Angela McCarthy, 'Migration and Madness at Sea: The Nineteenth- and Early TwentiethCentury Voyage to New Zealand', Social History of Medicine 28.4 (2015), 706-24 (715). As McCarthy notes, there were medical practitioners in the late nineteenth century who recommended a migratory 'voyage out and settlement abroad as a cure for mental and physical health', and by 'the twentieth century, emigration agents such as Thomas Cook publicised voyages as being "a charm" for health' (720)—an idea that has a long history, as evidenced by the notion that Hamlet, perhaps the world's most famous melancholic, might be refreshed by sea travel: 'Haply the seas, and countries different, / With variable objects, shall expel / This something-settled matter in his heart, / Whereon his brains still beating puts him thus / From fashion of himself' (William Shakespeare, Hamlet, Prince of Denmark, ed. Philip Edwards [Cambridge: Cambridge University Press, 1985], 3.1.165-69). But for the most part, seafaring has been seen as a tribulation rather than a cure.
} 
way of improving the mental health of sailors on contemporary cargo vessels-poorly paid, and often absent from their families for six months or longer-would be to provide them with unlimited access to the internet, thus allowing for video calls home. ${ }^{59}$

As we write this, long periods of social isolation brought about by the Covid-19 pandemic seem destined to result in mental health crises whose magnitude we are only just beginning to gauge, and there are certainly parallels to be drawn between our experiences and those of seafarers confined to small spaces and ripped from the comforts provided by friends and family. But we should not push these parallels too far: unlike us, seafarers were generally compelled into new forms of (often fraught) social interaction, as we have discussed, and rather than being confined to their homes, they were unhomed. Further, while the disruption of professional and social routines created by the pandemic has certainly disturbed our sense of time and created a similar notion that life is 'on hold', seafarers often experienced temporal disturbance in a more radical way. As we have noted, those crossing latitudes had their sense of seasonal progression disrupted, while the monotony of the sea-day confused notions of temporal progression. In his thoughtful exploration of sea voyage narratives, Robert Foulke observes that

[t]he seafarer's sense of time $[\ldots]$ is both linear and cyclical: Time is linear in the sense that voyages have beginnings and endings, departures and landfalls, starting and stopping points in the unfolding of chronological time; yet time is also cyclical, just as the rhythm of waves is cyclical, because the patterns of a ship's daily routine, watch on and watch off, highlights endless recurrence. ${ }^{60}$

The characteristics of experiencing space and time at sea-as simultaneously bounded and infinite, repetitive and constantly changing-are intertwined; as Foulke puts it, 'space and time have always merged more obviously at sea than they do in much of human experience'. ${ }^{61}$

\footnotetext{
${ }^{59}$ Entitled 'Ideas for Improving Seafarers' Mental Health and Wellbeing', the paper was delivered on 13 June 2019 at the University of Cardiff by Helen Sampson, and based on research carried out by her and by Neil Ellis. For a recent study of the lives of contemporary seafarers, see Victor Oyaro Gekara and Helen Sampson (eds.), The World of the Seafarer: Qualitative Accounts of Working in the Global Shipping Industry (Cham: Springer Nature, 2021).

${ }^{60}$ Foulke, Sea Voyage Narrative, 9.

${ }^{61}$ Foulke, Sea Voyage Narrative, 9.
} 


\section{Ships AS 'Places'}

While the 'endless recurrence' of a ship's routine could, in some instances, elicit nausea, it could also provide comfort. 'It is a great doctor for sore hearts and sore heads', writes Joseph Conrad; 'There is health in it, and peace, and satisfaction of the accomplished round [...] He who loves the sea also loves the ship's routine'. ${ }^{62}$ Conrad is describing the 'routine' of sailors: the patterns of labour that characterize professional seafaring. But his remarks could also be applied to passengers, who developed habits and rituals during long voyages, establishing order that helped compensate for an oceanic environment of flux and disorder. It is, in fact, by considering the ocean as a specific environment that we can better appreciate the significance, to seafarers, of the ship: often the only 'built environment' (to recall Tuan's expression) they would see for weeks on end. Looking over the sides of their vessel, or through their porthole, or from up in the rigging, seafarers saw something of which they could, at least initially, make little sense; ${ }^{63}$ turning inward to look on the ship itself, they saw a space which, while also initially alien, at least provided some degree of structure. Indeed, as another geographer, Tim Cresswell, has argued, even though ships are typically mobile, they have the capacity to become 'places'. By this he means that seafarers can develop relationships with their built environment in something like the way gestured towards by Tuan and Relph: places, Cresswell writes, can be defined as 'particular constellations of material things that occupy a particular segment of space and have sets of meanings attached to them'. ${ }^{64}$ The ship, or a specific place within a shipone's cabin or a mess room or the quarterdeck-can gain such definition. The two examples Cresswell gives when speaking of ships as places are, first, a vessel which 'may be shared for months on end by a crew of fishermen', and second, a passenger liner crossing the Atlantic in 1911 and providing not only a means of transport, but also a place within which American suffragists developed their political philosophy. ${ }^{65}$

\footnotetext{
${ }^{62}$ Joseph Conrad, The Mirror of the Sea (1907), in "A Personal Record" and "The Mirror of the Sea”, ed. Mara Kalnins (London: Penguin, 1998), 131-304 (150-1).

${ }^{63}$ Sketches of the sea and descriptions of its colour and texture found in shipboard diaries do, however, testify to seafarers' attempts to come to grips with the element in which they found themselves.

${ }^{64}$ Tim Cresswell, Geographical Thought: A Critical Introduction (Oxford: Wiley-Blackwell, 2013), 113. See also Tim Cresswell, On the Move: Mobility in the Modern Western World (London: Routledge, 2006), especially chapter 8.

${ }^{65}$ Cresswell, Geographical Thought, 113; Cresswell, On the Move, 201-207.
} 
Cresswell's examples - one dealing with professional seafarers and the other with passengers-should cause us once again to reflect on how a seafarer's specific status might inflect his or her relationship with a ship. Different types and sizes of vessels, and different lengths and conditions of voyaging, are further variables that significantly shape such relationships. While a vessel is only ever a temporary site for the passenger (often, indeed, a limbo-like place between an old home and a new one), changing technologies of seafaring and different rhythms of travel can also dictate the extent to which the passenger feels 'at home' while at sea. Andrew Hassam notes that in 'the later years of the nineteenth century the experience of making the voyage [to Australia] by steamer became quite different from the experience of those who went by sail'. One diary he cites to evidence this claim anticipates Conrad in its sense of the value of routine: 'Three months at sea $[\ldots]$ welded us into a community. The passengers did not spend their time counting the days to the next port, as passengers on a steamer do. They settled down to a daily round'. ${ }^{66}$

A number of practices aided in this 'place-making'. They include, for example, attempts to recreate domestic spaces on board through particular furnishings and through the display of familiar objects like pictures and books, as James R. Ryan has shown in his analysis of the Sunbeam, a sailing yacht used by Lady Brassey on her numerous world voyages in the late nineteenth century. ${ }^{67}$ Rather more modestly, steerage passengers on voyages of migration might decorate the walls adjoining their bunks, or name the narrow passageways between those bunks after streets from their home city. Over the coming pages, the essays by Chambers, Badcoe, and Pietsch will discuss similar forms of material place-making. But as this volume as a whole seeks to demonstrate, perhaps the most important means through which a ship gains spatial meaning for its inhabitants is through cultural activities: the kinds to which Hassam's diarist and his peers 'settled down'. These include communal activities such as ceremonies or performances, as well as more private activities such as reading and writing. If, for many seafarers, the ocean exists beyond culture, then the ship itself can, by contrast, become a cultural greenhouse. Limited space and the impossibility of escape intensify the significance of any cultural activity when compared

${ }^{66}$ Hassam, Sailing to Australia, 8.

${ }^{67}$ James R. Ryan, "“Our Home on the Ocean": Lady Brassey and the Voyages of the Sunbeam, 1874-1887', Journal of Historical Geography 32 (2006), 579-604. See also Fariha Shaikh, Nineteenth-Century Settler Emigration in British Literature and Art (Edinburgh: Edinburgh University Press, 2018). 
with its equivalent on land: the book you are reading will shape your daily experience more when there are few other stimuli; and there is more at stake in social interactions arising through communal performances when it will be difficult to avoid other participants for days or weeks afterwards.

As we indicated above in our reference to the ship's 'little world', populous ocean-going vessels are often conceived as microcosms of society, where social interactions are shaped by factors like class, gender, and religion, and where social boundaries are drawn based on behaviour, expectations, and preconceptions. ${ }^{68}$ The notion of the ship as a microcosm of society is perhaps most apt when considering passenger vessels, whether migrant ships of the eighteenth and nineteenth centuries or the later passenger steamers; it is less useful when thinking about other kinds of vessels and about groups of travellers more uniform in their composition. (Even in the case of migrants, a relative homogeneity of background can make the 'microcosm' model of limited use.) Yet, leaving such justified criticism aside, considering ships as spaces that give shape to and host a society in miniature does alert us to several factors that have implications for how voyages are lived out: the significance of interpersonal relationships and the importance of a community; the formation and maintenance of individual and collective identities; and the enduring connection between land-based lives and practices and onboard experiences.

One extraordinary passage composed by Richard Henry Dana, Jr., provides an indication of the peculiar qualities of social life at sea. Dana is describing the aftermath of the loss overboard of a young English sailor:

at sea-to use a homely but expressive phrase-you miss a man so much. A dozen men are shut up together in a little bark on the wide, wide sea, and for months and months see no forms and hear no voices but their own, and one is taken suddenly from among them, and they miss him at every turn. It is like losing a limb. There are no new faces or new scenes to fill up the gap. There is always an empty berth in the forecastle, and one man wanting when the small night-watch is mustered. There is one less to take the wheel, and

\footnotetext{
${ }^{68} \mathrm{John}$ Mack argues for the interdependency of a ship's crew, rather than the heterogeneous nature of travellers on board ship, as rendering the ship a microcosm of society: 'As on any ship the crew are so involved in each others' activities and so dependent on each others' skills for the successful completion of their quest that the ship becomes an enclosed social world, a microcosm of wider social situations' (The Sea: A Cultural History, 145). Similarly, Paul Gilroy describes a ship as 'a living, micro-cultural, micro-political system in motion' in Black Atlantic, 4. Robert Foulke notes that frequently in voyage narratives 'the small world of the ship serves as a microcosm of civilization as a whole' (Sea Voyage Narrative, 11).
} 
one less to lay out with you upon the yard. You miss his form, and the sound of his voice, for habit had made them almost necessary to you, and each of your senses feels the loss. ${ }^{69}$

Dana is recording a specific form of shipboard experience: that of the professional seafarer working a ship of sail and living in the cramped conditions of the forecastle ('before the mast'). But his remarks are transferrable to most shipboard environments, which are characterized by an intimacy that makes interpersonal relations especially significant and by rigid routines that make deviations especially meaningful. In such environments, the following essays demonstrate, literary activities - whether a turning 'in' towards private reading and writing, or a turning 'out' towards one's fellow seafarers through shared reading and communal performancestake on unusual resonances, and substantially frame voyage experiences.

\section{The Sea as Element}

These experiences, we have been arguing, take place within two interlocking spatial contexts: the ship, as a physical as well as socially and culturally constructed space; and the material environment of the sea. It is surprisingly easy, when studying maritime culture, to lose sight of the latter. Anyaa Anim-Addo, William Hasty, and Kimberley Peters analyse different forms of mobility to be found on ships, noting that we need to think of the ship both 'as a mover of things' and as a 'moving thing' ${ }^{70}$ In addition, we would wish to stress, a third type of mobility shapes oceanic experiences: that of the sea itself. The stain in Edward Beck's diary is a physical reminder of an elemental presence whose intrusion into the ship is, in many cases, a continual occurrence. Analysing one nineteenth-century diarist's reference to their ship as a 'floating home', Andrew Hassam asserts that the expression 'nicely captures the instability of space on board ship, the combination of an enclosed space and the moving vessel'.$^{71}$ But the ship is not, we would want to insist, a fully 'enclosed' space; rather, its contents are in continual exchange with the element on which the ship

\footnotetext{
${ }^{69}$ Richard Henry Dana, Jr., Two Years Before the Mast: A Personal Narrative (New York: Signet Classics, 2009), 31. John Mack also draws on this passage in Dana's writing, but to highlight instead the ways in which the lives and actions of seafarers are dependent on each other while on board ship and at sea (The Sea: A Cultural History, 137).

${ }^{70}$ Anyaa Anim-Addo, William Hasty, and Kimberley Peters, 'The Mobilities of Ships and Shipped Mobilities', Mobilities 9.3 (2014), 337-349 (338).

${ }^{71}$ Hassam, Sailing to Australia, 68.
} 
'floats'. Sister Mulquin, the subject of Chap. 7, like many shipboard diarists records more than one soaking in rough seas. Equally, objects on the ship enter the sea: diaries report the loss overboard of a range of items including hats, books, beer bottles, livestock, needlework, navigational instruments, and cricket balls. They also record how fish and other sea creatures were drawn onto the ship and consumed or dissected; how water invaded holds and needed to be pumped out again; and how decks remained treacherously wet for weeks on end, inhibiting the kinds of activities that helped keep passengers healthy and cheerful during a long voyage, like walking, sports, or sitting on deck. Most poignantly, they record the assimilation into the sea of people: either those who fell (or jumped) overboard, or those who, perishing in mid-ocean, were-in that powerful expression-'committed to the deep'.

Even those who stayed within the bounds of the ship were, in a range of ways, affected by the sea itself. As we have noted above, it is the specific dangers presented by the sea-those of shipwreck and drowning-that require the creation of such pronounced hierarchies on board ships; and the sense of disorientation suffered by those who take to sea, we have argued, is created not only by distance from any built environment (as would also be the case in, for example, the desert), but also by the instability generated by water's molecular structure. Fuller attention to the sea as a material substance can extend the horizons of maritime studies. 'The time has come', wrote Helen Rozwadowski in 2012, 'for scholars in the humanities to try to understand that the ocean is not only $[. .$.$] a stage for$ the events of human history, but rather a complex and changing natural environment that is inextricably connected to, and influenced by, people'. ${ }^{72}$ The interdependence of humans and oceans takes several forms. Powered by the burning of fossil fuels, ships crossing the oceans indirectly change the chemical composition of the oceans they cross and, in turn, affect creatures for whom the oceans are home; and, like sail-driven vessels, they transport on hulls or as ballast organisms which, deposited in another part of the ocean, reshape local ecosystems. Equally, and as we have begun to suggest, interactions with the sea affect human bodies, personalities, and language.

These interactions might be helpfully theorized by recent work in the new materialism that stresses the 'entanglements' of humans and nonhumans, steering us away from the dangerous shoals of human

\footnotetext{
${ }^{72}$ Helen M. Rozwadowski, 'Arthur C. Clarke and the Limitations of the Ocean as a Frontier', Environmental History 17.3 (2012), 578-602 (583).
} 
exceptionalism by urging us to think in terms of 'collectives' and 'assemblages' that include animals, as well as other 'things' or 'objects' granted agency. ${ }^{73}$ Maritime studies has always, in fact, been alert to the role of nonhuman entities (such as currents and winds) in forging human history, and it also pays careful attention to machines-that is, ships-that are understood to have personalities and desires of their own; and to some extent, Rozwadowski's call for greater attention in maritime history to oceans as environments (rather than merely surfaces to be crossed) has been heard over the past decade. ${ }^{74}$ But there remains scope, we would suggest, for maritime studies to bring into even greater focus the ocean's material presence. If we are to think really seriously about what happens to humans at sea, then we must treat the ship not simply as one place moving between other, static, places, but rather as one in dynamic relationship with an ocean whose material structure and inhabitants have the capacity, in various ways, to shape the outcomes and the experiences of voyages. ${ }^{75}$

Enhanced awareness of the sea as element can be achieved, in part, through attention to shipboard literary cultures. Phenomena like the stain in Beck's diary are reminders of the sea as a specific environment; like grains of sand found in a book read on a beach several years previously, they are markers of place-specific cultural activity. Even if most of the

\footnotetext{
${ }^{73}$ See, in particular, Jane Bennett, Vibrant Matter: A Political Ecology of Things (Durham and London: Duke University Press, 2010). Other key works in related areas of scholarship, all of which seek, in some way, to break down notions of human exceptionalism, would include Bruno Latour, Politics of Nature: How to Bring the Sciences into Democracy, trans. Catherine Porter (Cambridge, Mass. and London: Harvard University Press, 2004 [1999]); Graham Harman, Tool-Being: Heidegger and the Metaphysics of Objects (Chicago: Open Court, 2002); Karen Barad, Meeting the Universe Halfway: Quantum Physics and the Entanglement of Matter and Meaning (Durham, NC: Duke University Press, 2007); Donna Haraway, When Species Meet (Minneapolis: University of Minnesota Press, 2007). A scholar notable for bringing the philosophical perspectives found in such work to marine contexts is Stacy Alaimo: see, in particular, Exposed: Environmental Politics and Pleasures in Posthuman Times (University of Minnesota Press, 2016).

${ }^{74}$ As the editors of Oceanic Histories note, 'Environmental history has helped turn a longstanding historiography of humans, vessels and exploration [i.e. maritime history], toward analysis of complex relations between elements (winds, tides, currents), ocean life (mammals, fish, crustaceans, birds, plants), and human activity in and on the seas' (13). For an early and extraordinary example of such work, see Marcus Rediker, 'History from below the Water Line: Sharks and the Atlantic Slave Trade', Atlantic Studies 5.2 (2008), 285-297.

${ }^{75}$ Kimberley Peters elsewhere draws attention to the sea 'as a more-than-human nature; a material entity through which force operates and human affects are elicited' ('Taking MoreThan-Human Geographies to Sea: Ocean Natures and Offshore Radio Piracy', in Anderson and Peters [eds], Water Worlds, 177-91 [188]).
} 
sea-stains with which the following pages deal are metaphorical rather than literal, several of our contributors are concerned with how the shipboard literary cultures on which they focus were affected by seas of different kinds and by their associated climates and inhabitants. We might, in fact, at least in some instances consider literary practices as a means of trying to forget the frightening element that surrounded seafarers - that is, as a deliberate act of hydrophasia. At the beginning of the twentieth century, Calvin Winter advised against including any 'books of the sea' in ships' libraries on passenger steamers, as 'Travellers who are not good sailors read for the purpose of forgetting where they are'. ${ }^{76}$ Of course, forgetting or ignoring one's surroundings is impossible for some kinds of professional seafarer, most obviously those involved in the fisheries. But even Richard Henry Dana, Jr., a sailor who needed to know the ways of the sea and to measure its depths, was aware that to reflect too precisely on deep water itself was to risk becoming paralysed by fear and abhorrence:

There is something in the first gray streaks stretching along the eastern horizon and throwing an indistinct light upon the face of the deep, which combines with the boundlessness and unknown depth of the sea around, and gives one a feeling of loneliness, of dread, and of melancholy foreboding, which nothing else in nature can. This gradually passes away as the light grows brighter, and when the sun comes up, the ordinary monotonous sea day begins. ${ }^{77}$

Dana's almost unconscious echo of Genesis 1:2 frames the relationship between the human and the sea, or the ship and the ocean, as one between order and disorder; the sea's vertical axis, all the more frightening for being of unknown extent, heaves into view. And it is, to recall Conrad, a ship's routine - made up of labour, but also of literary culture - that helps distract the seafarer from whatever awful truth is suggested by the sea.

\section{The Voyage Ahead}

The essays that follow explore reading, writing, and performing at sea in various combinations and are ordered chronologically. Chapter 2, by Christian Algar, argues that reading material taken aboard a man-of-war

\footnotetext{
${ }^{76}$ Calvin Winter, 'The Libraries on the Trans-Atlantic Liners', The Bookman 33 (1911), 368-375 (375).

${ }^{77}$ Dana, Two Years Before the Mast, 6.
} 
during the English Civil War by the Puritan chaplain John Syms led to a disruption in the ship's hierarchy. Engaging with scholarship on the 'where' of reading, the reading practices of Puritanism, and the history of religious figures on board military ships, Algar offers our first example of how literary practices might disturb the delicate balance of a shipboard community. In Chap. 3, Stephen Berry similarly explores the intersections between maritime and religious cultures. In this essay, however, the focus is on how literary cultures might forge-rather than disturb-bonds between shipmates. British sailing ships of the eighteenth century, Berry argues, became distinct sites for religious reading and writing; and such activities provided opportunities for the exchange of books and for learning together, in the process bringing into close contact seafarers from diverse ethnic and cultural backgrounds. Chapter 4, by Mary Isbell, returns us to a military vessel, the USS Macedonian, but examines a different form of literary culture: the production of theatricals and newspapers. Like Algar, Isbell pieces together evidence for onboard altercations through limited extant materials, in her case the journal of Lieutenant Charles Gauntt kept between 1818 and 1821. Bringing scholarship on shipboard theatricals into conversation with that on shipboard newspapers, she argues that to appreciate the meanings and effects of onboard performances we need to remain alert to how those watching them recognized performers as their fellow shipmates.

The following three chapters, all by literary scholars, offer close readings of shipboard diaries. Comparing the diary kept by Edward Beck during a transatlantic voyage in the 1820s with one kept by Margaret MacGillivray, a passenger travelling from England to Australia in the 1890s, Eli Cumings and Laurence Publicover argue in Chap. 5 that both seafarers kept diaries as a means of orienting themselves in novel environments; but while MacGillivray was aiming to accommodate herself to what was only a temporary home, they demonstrate, Beck kept his diary as a means of developing his professional identity. In Chap. 6, Jimmy Packham examines logbooks and diaries written aboard American whaleships in the 1860s and 1870s. Like Cumings and Publicover, he works with two mutually illuminating case studies: one diary written by a whaler of thirty-three years' experience, and another written by a six-year-old girl on her father's whaleship. Engaging with recent scholarship in oceanic studies to explore the work and significance of maritime life writing, Packham is especially interested in how these documents reveal their authors' interactions with nonhumans-whales, of course, but also other creatures-and how they 
illuminate the vast oceanic networks through which whaleships moved. In Chap. 7, Tamsin Badcoe examines the diary of Sister Mary Paul Mulquin, kept during her 1873 voyage from Liverpool to Australia on board Isambard Kingdom Brunel's SS Great Britain. Like Packham, Badcoe is concerned with the intersection of individual experiences with more global histories, in her case of colonization and religious conflict; and like Algar and Berry, she explores the place of religious practice in structuring (and sometimes unsettling) shipboard communities.

Chapter 8, by Helen Chambers, focuses on the literary culture of a ship previously encountered in the essay by Cumings and Publicover: the Torrens, a clipper that ran between England and Australia in the late nineteenth century. Chambers draws on the few extant passenger diaries and letters written aboard this ship to argue that-with its predominantly firstclass, well-educated passengers - the Torrens provided a uniquely privileged moving environment for private and shared reading, for writing, and for musical performances. Chambers is especially concerned to demonstrate how such activities shaped and sometimes complicated shipboard dynamics, providing opportunities for establishing and expanding onboard communities. The role of literary culture in creating and maintaining communal identities and cohesion is also a concern of Susann Liebich's essay. In Chap. 9, Liebich analyses troopship magazines produced and circulated on New Zealand soldier transports during World War I, demonstrating how such publications mediated and reflected the process of spatial and biographical transit. The practices of writing, editing, and reading troopship magazines, as well the ways in which such publications constructed sea travel as a shared experience, she argues, forged a sense of community both on board the ship and into an uncertain future. The space of the ocean and of the troopship are acutely present in these magazines, as is the wider context of war. The role of reading materials produced and circulated on board is also examined in Chap. 10, in which Tamson Pietsch follows the progress of the 'Floating University': a pedagogical experiment led by New York University's Professor of Psychology, James Edwin Lough, which involved taking 500 American university students on an eight-month voyage around the world in 1926-27. These students produced a shipboard newspaper, The Binnacle, which-as its title would suggest - offered a kind of navigational aid for the ship's passengers. Pietsch examines this and other surviving documents to consider how the geography of the ship and the sites through which it passed shaped the education those voyagers received. 
Taking us into the present but drawing on the many pasts outlined across these essays, David Punter's Afterword (Chap. 11) reflects on how the sediments of prior encounters with the oceans, stirred by fresh readings of older texts, form part of our present engagement with the oceans and with those that cross them. He centres his wide-ranging discussions on Horatio Clare's 2014 book Down to the Sea in Ships: Of Ageless Oceans and Modern Men, a travelogue recounting Clare's experiences on container ships. In this introduction, we have tended to contrast the socially constructed environment of the ship with the material fact of the sea, but Punter's essay works towards complicating this distinction, indicating how far notions and experiences of the oceans are themselves constructed through reading and writing. In addition, while the essays in this collection examine actual literary practices within specific historical contexts, Punter takes this task one step further, or rather sideways, by offering a broader consideration of how earlier sea narratives-some read by Clare prior to his journey, others existing as part of the canon of sea literaturealso shape this contemporary journey on a container ship, inflecting a narrative that is itself produced at sea. Punter's essay, then, invites us to consider the ways in which the seas of the past seep into the present, staining, in their peculiar ways, the relations between humans and oceans.

\section{BibLIOGRAPHY}

Alaimo, Stacy, Exposed: Environmental Politics and Pleasures in Posthuman Times (Minneapolis: University of Minnesota Press, 2016)

Anderson, John, and Kimberley Peters, "“A perfect and absolute blank": Human Geographies of Water Worlds', in Anderson and Peters (eds), Water Worlds: Human Geographies of the Ocean (Farnham: Ashgate, 2014), 3-19

Anim-Addo, Anyaa, William Hasty, and Kimberley Peters, 'The Mobilities of Ships and Shipped Mobilities', Mobilities 9.3 (2014), 337-349

Armitage, David, Alison Bashford, and Sujit Sivasundaram, 'Introduction: Writing World Oceanic Histories', in Armitage, Bashford, and Sivasundaram (eds), Oceanic Histories (Cambridge: Cambridge University Press, 2018), 1-27

Bacon, Sir Francis, The Major Works, ed. Brian Vickers (Oxford: Oxford University Press, 1996)

Barad, Karen, Meeting the Universe Halfway: Quantum Physics and the Entanglement of Matter and Meaning (Durham, NC: Duke University Press, 2007)

Barbour, Richmond, and Bernhard Klein, 'Drama at Sea: A New Look at Shakespeare on the Dragon', in Claire Jowitt and David McInnis (eds), Travel 
and Drama in Early Modern England: The Journeying Play (Cambridge: Cambridge University Press, 2018), 150-168

Beck, Edward, The Sea Voyages of Edward Beck in the 1820s, ed. Kenneth M. Hay and Joy Roberts (Durham: The Pentland Press, 1996)

Bell, Bill, 'Print Culture in Exile: the Scottish Emigrant Reader in the Nineteenth Century', Papers of the Bibliographical Society of Canada 36.2 (1998), 87-106

— 'Bound for Australia: Shipboard Reading in the Nineteenth Century', Journal of Australian Studies 25.68 (2001), 5-18

Bennett, Jane, Vibrant Matter: A Political Ecology of Things (Durham and London: Duke University Press, 2010)

Berry, Stephen R., A Path in the Mighty Waters: Shiphoard Life of Atlantic Crossings to the New World (New Haven: Yale University Press, 2015)

Beuger, Christian, and Tim Edmunds, 'Beyond Seablindness: A New Agenda for Maritime Security Studies', International Affairs 93.6 (2017), 1293-1311

Blum, Hester, The View from the Masthead: Maritime Imagination and Antebellum American Sea Narratives (Chapel Hill: University of North Carolina Press, 2008)

'The Prospect of Oceanic Studies', PMLA 125.3 (2010), 670-77

'Introduction: Oceanic Studies', Atlantic Studies 10.2 (2013), 151-5

The News from the Ends of the Earth: The Print Culture of Polar Exploration (Durham, NC: Duke University Press, 2019)

Boswell, James, James Boswell's Life of Johnson: An Edition of the Original Manuscript, ed. Marshall Waingrow, Vol. I: 1709-1765 (Edinburgh, New Haven, and London: Edinburgh University Press and Yale University Press, 1996)

Bruster, Douglas, 'Local Tempest: Shakespeare and the Work of the Early Modern Playhouse', in Patrick M. Murphy (ed.), The Tempest: Critical Essays (London: Routledge, 2001), 257-275

Burke, Peter, 'Historicizing the Self, 1770-1830', in Arianne Baggerman (ed.), Controlling Time and Shaping the Self: Developments in Autobiographical Writing Since the Sixteenth Century (Leiden: Brill, 2011), 13-32

Carter, Kathryn, 'Accounting for Time in Nineteenth-Century Manuscript Diaries and Photographs', Life Writing 12.4 (2015), 417-430

Chartier, Roger, The Order of Books, trans. Lydia G. Cochrane (Cambridge: Polity Press, 1994)

Christopher, Emma, Cassandra Pybus and Marcus Rediker (eds), Many Middle Passages: Forced Migration and the Modern World (Berkeley: University of California Press, 2007)

Cohen, Margaret, The Novel and the Sea (Princeton: Princeton University Press, 2010)

Colclough, Stephen, 'Recovering the Reader: Commonplace Books and Diaries as Sources of Reading Experience', Publishing History 44 (1998), 5-37 
Coons, Lorraine, "From "Company Widow" to "New Women": Female Seafarers aboard the "Floating Palaces" of the Interwar Years', International Journal of Maritime History 20.2 (2008), 143-74

Conrad, Joseph, The Mirror of the Sea (1907), in Mara Kalnins (ed.), "A Personal Record" and "The Mirror of the Sea" (London: Penguin, 1998), 131-304

L Lord Jim: A Tale, ed. Allan H. Simmons (London: Penguin Classics, 2007)

Cresswell, Tim, On the Move: Mobility in the Modern Western World (London: Routledge, 2006)

- Geographical Thought: A Critical Introduction (Oxford: WileyBlackwell, 2013)

Dana, Jr., Richard Henry, Two Years Before the Mast: A Personal Narrative (New York: Signet Classics, 2009)

Darnton, Robert, 'First Steps Toward a History of Reading', in The Kiss of Lamourette: Reflections in Cultural History (New York: W. W. Norton, 1990), 154-187

Dekker, Rudolf, Introduction, in Rudolf Dekker (ed.), Egodocuments and History: Autobiographical Writing in Its Social Context since the Middle Ages (Hilversum: Verloren, 2002), 7-20

Dening, Greg, Mr Bligh's Bad Language (Cambridge: Cambridge University Press, 2010)

Druett, Joan, Petticoat Whalers: Whaling Wives at Sea (Auckland: Collins, 1991)

- She Captains: Heroines and Hellions of the Sea (New York: Simon \& Schuster, 2000)

Edwards, Philip, Sea-Mark: The Metaphorical Voyage, Spenser to Milton (Liverpool: Liverpool University Press, 1997)

Foxhall, Katherine, Health, Medicine and the Sea: Australian Voyages, c. 1815-1860 (Manchester: Manchester University Press, 2012)

Foulke, Robert, The Sea Voyage Narrative (New York: Routledge, 1997)

Frost, Simon, 'A Trade in Desires: Emigration, A.C. Gunter and the Home Publishing Company', in Nicola Wilson (ed.), The Book World: Selling and Distributing Literature, 1900-1940 (Leiden: Brill, 2016), 31-51

Gekara, Victor Oyaro, and Helen Sampson (eds), The World of the Seafarer: Qualitative Accounts of Working in the Global Shipping Industry (Cham: Springer Nature, 2021)

Gillis, John R., Islands of the Mind: How the Human Imagination Created the Atlantic World (Basingstoke: Palgrave Macmillan, 2004)

'The Blue Humanities', Humanities 34.3 (2013)

Gilroy, Paul, The Black Atlantic: Modernity and Double Consciousness (London: Verso, 1993)

Gordon, George, Lord Byron, Poetical Works, ed. Frederick Page, new ed. corrected by John Jump (London: Oxford University Press, 1970)

Haraway, Donna, When Species Meet (Minneapolis: University of Minnesota Press, 2007) 
Harman, Graham, Tool-Being: Heidegger and the Metaphysics of Objects (Chicago: Open Court, 2002)

Hassam, Andrew, Sailing to Australia: Shipboard Diaries by Nineteenth-Century British Emigrants (Manchester: Manchester University Press, 1994)

Hastings, David, Over the Mountains of the Sea: Life on the Migrant Ships 1870-1885 (Auckland: Auckland University Press, 2006)

Hasty, William, and Kimberley Peters, 'The Ship in Geography and the Geographies of Ships', History Compass 6.11 (2012), 660-676

Hofmeyr, Isabel, 'The Complicating Sea: The Indian Ocean as Method', Comparative Studies of South Asia, Africa and the Middle East 32.3 (2012), 584-590

Holmes, Katie, 'Marking Time: Australian Women's Diaries of the 1920s and 1930s', in Arianne Baggerman (ed.), Controlling Time and Shaping the Self: Developments in Autobiographical Writing Since the Sixteenth Century (Leiden: Brill, 2011), 169-196

Hovde, David M., 'Benevolence at Sea: Shipboard Libraries for the American Navy and Merchant Navy', in Robert S. Freeman and David M. Hovde (eds), Libraries to the People: Histories of Outreach (Jefferson: McFarlane \& Company, 2003), 50-72

Keighren, Innes M., 'Geographies of the Book: Review and Prospect', Geography Compass 7.11 (2013), 745-758

Klein, Bernhard, and Gesa Mackenthun (eds), Sea Changes: Historicizing the Ocean (London: Routledge, 2003)

Koselleck, Reinhard, Vergangene Zukunft: Zur Semantik geschichtlicher Zeiten (Frankfurt: Suhrkamp, 1979)

Latour, Bruno, Politics of Nature: How to Bring the Sciences into Democracy, trans. Catherine Porter (Cambridge, Mass. and London: Harvard University Press, 2004 [1999])

Leane, Elizabeth, South Pole: Nature and Culture (London: Reaktion, 2016)

Lefebvre, Henri, The Production of Space, trans. Donald Nicholson-Smith (Oxford: Blackwell, 1991 [1974])

Lejeune, Philippe, On Diary, ed. Jeremy D. Popkin and Julie Rak, trans. Katherine Durnin (Honolulu: University of Hawai'i Press, 2009)

Liebich, Susann, 'A Sea of Fiction: The Libraries of Trans-Pacific Steamships at the Turn of the Twentieth Century', The Library 20.1 (2019), 3-28

Livingstone, David N., 'Science, Text and Space: Thoughts on the Geography of Reading', Transactions of the Institute of British Geographers 30.4 (2005), 391-401

McCarthy, Angela, 'Migration and Madness at Sea: The Nineteenth- and Early Twentieth-Century Voyage to New Zealand', Social History of Medicine 28.4 (2015), 706-24

Mack, John, The Sea: A Cultural History (London: Reaktion, 2011) 
Maenpaa, Sari, 'Women below Deck: Gender and Employment on British Passenger Liners, 1860-1938', The Journal of Transport History 25.2 (2004), 57-74

Massey, Doreen, For Space (London: SAGE, 2005)

Melville, Herman, Moby-Dick, ed. Toby Tanner (Oxford: Oxford University Press, 1998)

Mentz, Steve, 'Toward a Blue Cultural Studies: The Sea, Maritime Studies, and Early Modern English Literature', Literature Compass 6.5 (2009), 997-1013

- Shipwreck Modernity: Ecologies of Globalization, 1550-1719 (Minneapolis and London: University of Minnesota Press, 2015)

Mukherjee, Rila, 'Escape from Terracentrism: Writing a Water History', Indian Historical Review 41 (2014), 87-101

Ogborn, Miles, and Charles W. J. Withers, 'Introduction: Book Geography, Book History', in Ogborn and Withers (eds), Geographies of the Book (Farnham: Ashgate, 2010), 1-25

Peters, Kimberley, 'Taking More-Than-Human Geographies to Sea: Ocean Natures and Offshore Radio Piracy', in Jon Anderson and Kimberley Peters (eds), Water Worlds: Human Geographies of the Ocean (Farnham: Ashgate, 2014), 177-191

Preedy, Chloe, and Laurence Publicover (eds), 'Space on the Early Modern Stage', special issue of Cabiers Élisabéthains 88.1 (2015), 7-180

Rediker, Marcus, Between the Devil and the Deep Blue Sea: Merchant Seamen, Pirates, and the Anglo-American Maritime World, 1700-1750 (Cambridge: Cambridge University Press, 1987)

The Slave Ship: A Human History (New York: Penguin, 2007)

'History from below the Water Line: Sharks and the Atlantic Slave Trade', Atlantic Studies 5.2 (2008), 285-297

Relph, Edward, Place and Placelessness (London: Pion, 1976)

Rozwadowski, Helen M., Fathoming the Ocean: The Discovery and Exploration of the Deep Sea (Cambridge, Mass.: Harvard University Press, 2005)

'Arthur C. Clarke and the Limitations of the Ocean as a Frontier', Environmental History 17.3 (2012), 578-602

- Vast Expanses: A History of the Oceans (London: Reaktion, 2018)

Ryan, James R., "OUr Home on the Ocean": Lady Brassey and the Voyages of the Sunbeam, 1874-1887', Journal of Historical Geography 32 (2006), 579-604

Schmidt, Johanna de, "This strange little floating world of ours": Shipboard Periodicals and Community-building in the "Global" Nineteenth Century', Journal of Global History 11 (2016), 229-250

Sekula, Allan and Noël Burch (dir.), The Forgotten Space (Doc.Eye Films and Icarus Films, 2010)

Shaikh, Fariha, Nineteenth-Century Settler Emigration in British Literature and Art (Edinburgh: Edinburgh University Press, 2018) 
Shakespeare, William, Hamlet, Prince of Denmark, ed. Philip Edwards (Cambridge: Cambridge University Press, 1985)

Skallerup, Harry R., Books Afloat \& Ashore: A History of Books, Libraries, and Reading among Seamen during the Age of Sail (Hamden: Archon Books, 1974)

Smallwood, Stephanie, Saltwater Slavery: A Middle Passage from African to American Diaspora (Cambridge: Harvard University Press, 2007)

Stanley, Jo, From Cabin 'Boys' to Captains: 250 Years of Women at Sea (Stroud, Gloucestershire: The History Press, 2016)

Women and the Royal Navy (London: IB Taurus, 2017)

Steinberg, Philip, The Social Construction of the Ocean (Cambridge: Cambridge University Press, 2001)

_ 'Of Other Seas: Metaphors and Materialities in Maritime Regions', Atlantic Studies 10.2 (2013), 156-169

Swift, Jonathan, Gulliver's Travels, ed. Claude Rawson (Oxford: Oxford University Press, 2005)

Tuan, Yi-Fu, Space and Place: The Perspective of Experience (Minneapolis: University of Minnesota Press, 1977)

Wallace, David Foster, A Supposedly Fun Thing I'll Never Do Again: Essays and Arguments (London: Little, Brown, 1997)

Wenzlhuemer, Roland, and Martin Dusinberre, 'Editorial - Being in Transit: Ships and Global Incompatibilities', Journal of Global History 11 (2016), 1-8

Wigen, Kären (ed.), 'Oceans in History', special edition of American Historical Review 111.3 (2006), 717-80

Winter, Calvin, 'The Libraries on the Trans-Atlantic Liners', The Bookman 33 (1911), 368-375

Open Access This chapter is licensed under the terms of the Creative Commons Attribution 4.0 International License (http://creativecommons.org/licenses/ by $/ 4.0 /)$, which permits use, sharing, adaptation, distribution and reproduction in any medium or format, as long as you give appropriate credit to the original author(s) and the source, provide a link to the Creative Commons licence and indicate if changes were made.

The images or other third party material in this chapter are included in the chapter's Creative Commons licence, unless indicated otherwise in a credit line to the material. If material is not included in the chapter's Creative Commons licence and your intended use is not permitted by statutory regulation or exceeds the permitted use, you will need to obtain permission directly from the copyright holder.

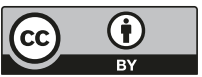

